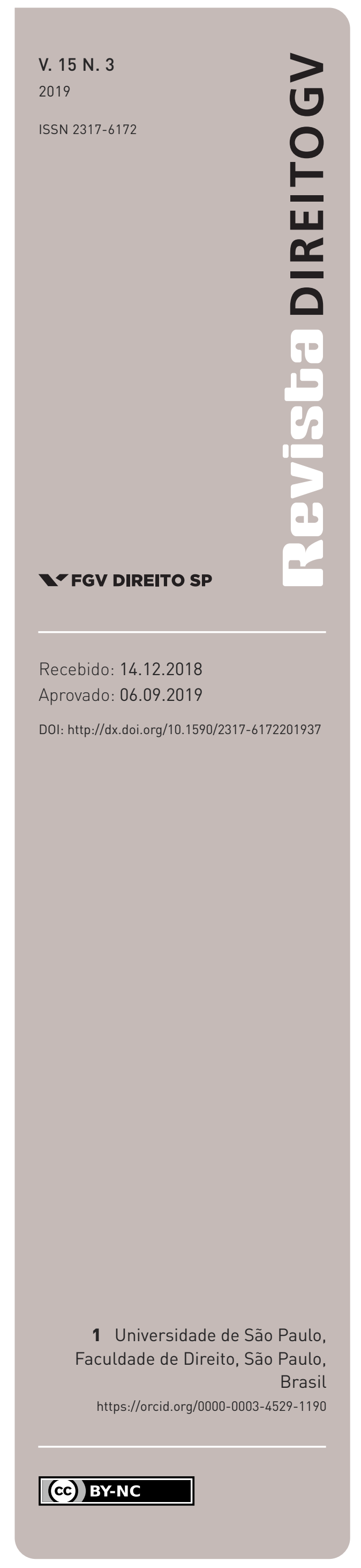

\title{
O dolo da improbidade administrativa: uma busca racional pelo elemento subjetivo na violação aos princípios da Administração Pública
}

\author{
MALICE IN ADMINISTRATIVE IMPROBITY: A RATIONAL QUEST FOR THE SUBJECTIVE \\ ELEMENT IN THE VIOLATION OF THE PRINCIPLES OF PUBLIC ADMINISTRATION
}

Vivian Maria Pereira Ferreira'

\section{Resumo}

Este artigo investiga a jurisprudência do Superior Tribunal de Justiça (STF) na aplicação da Lei de Improbidade Administrativa, enfocando o debate sobre a necessidade de demonstração de dolo para que se responsabilize o agente público por violação aos princípios da Administração Pública. A partir da análise qualitativa dos argumentos trazidos pelos ministros ao decidir o Recurso Especial (REsp) n. 765.212/AC, caso no qual a questão foi mais profundamente debatida, verifica-se que falta clareza ao STF para lidar com os conceitos de "intenção" e "vontade" e que, embora as conclusões dos ministros sejam convergentes, os argumentos mobilizados escondem diferenças teóricas profundas, que não podem ser ignoradas se se pretende uma aplicação racional e inteligível da Lei de Improbidade Administrativa. Com vistas a enriquecer o debate sobre o tema, propõe-se um resgate teórico da noção aristotélica de razão prática, que permite distinguir mais eficientemente a conduta ilegal da conduta ímproba. Aponta-se, ainda, que a compreensão da inteligibilidade da ação do agente público acusado de improbidade depende de uma análise de contexto, bem como da clareza de que o administrador age no sentido de realizar projetos, e não apenas para evitar a ilegalidade, o que deve transparecer na motivação das decisões judiciais em ações de improbidade administrativa.

\section{Palavras-chave}

Improbidade administrativa; dolo; ação racional; razão prática; fundamentação jurídica.

\section{Abstract}

This article examines the application of the Law of Administrative Improbity by the Brazilian Superior Court of Justice (STJ), focusing on the debate about the need of demonstration of intent to hold the public agent accountable for violating the principles of Public Administration. Based on qualitative analysis of the arguments used in deciding the REsp n. 765.212/AC (special appeal in which the issue was more deeply discussed), it appears that the Court lacks clarity to deal with the concepts of 'intention' and 'will'. And although the conclusions of the judges converge, the arguments they mobilize conceal deep theoretical differences, which cannot be ignored for a rational and intelligible application of the Law. Aiming at enriching this debate, the article proposes a recovery of the Aristotelian notion of practical reason, which allows for a more efficient distinction between illegal conduct and administrative improbity. It is also pointed out that understanding the intelligibility of human action depends on context analysis. Moreover, the fact that the public agent acts to carry out policies, and not only to avoid illegality, must be taken into consideration by courts. When deciding actions of administrative improbity judges must, therefore, address these matters.

\section{Keywords}

Administrative improbity; malice; rational action; practical reason; legal reasoning. 


\section{INTRODUÇÃO*}

A Constituição de 1988 protege como princípios basilares do Estado Democrático de Direito a moralidade e a probidade administrativa. ${ }^{1}$ Prevê, nesse sentido, punição severa aos agentes públicos que atuem de forma desonesta e desleal no exercício das suas funções, com potencial prejuízo à Administração Pública, podendo resultar na suspensão dos seus direitos políticos, na perda da função pública, na indisponibilidade dos seus bens e na sua condenação ao ressarcimento do erário. ${ }^{2}$

A regulação do procedimento para a imposição de tais sanções foi delegada pelo constituinte de 1988 ao legislador ordinário e veio a lume alguns anos depois, com a edição da Lei n. 8.429, sancionada pelo Presidente Fernando Collor em junho de 1992, em meio a um notório escândalo de corrupção. ${ }^{3}$

Em linhas gerais, a Lei de Improbidade Administrativa (LIA) distingue três tipos de condutas ímprobas: os atos que importam enriquecimento ilícito (art. $9^{\circ}$ ), os atos que causam prejuízo ao erário (art. 10), e os atos que atentam contra os princípios da Administração Pública (art. 11). A lei tem um escopo bastante amplo, sujeitando à punição por improbidade administrativa quaisquer agentes públicos, bem como os agentes privados eventualmente beneficiados pelas condutas ali tipificadas.

$\mathrm{Na}$ interpretação e aplicação dos referidos dispositivos, persistiu, por algum tempo, uma controvérsia quanto à necessidade de demonstração de dolo ou culpa para que se proceda à efetiva responsabilização do agente pelas condutas previstas na LIA. Isso porque somente o artigo 10 , relativo aos atos de improbidade que causam prejuízo ao erário, faz referência expressa ao elemento subjetivo do agente, abarcando qualquer ação ou omissão dolosa ou culposa. Já os outros dois preceitos nada dispõem a esse respeito.

* O presente artigo é fruto do desenvolvimento de uma pesquisa de doutorado em andamento.

$1 \mathrm{O}$ artigo $5^{\circ}$ da Constituição expressamente prevê, em seu inciso LXXIII, que qualquer cidadão é parte legítima para propor ação popular que vise a anular ato lesivo ao patrimônio público ou à moralidade administrativa. Ademais, ao tratar da Administração Pública, o artigo 37 da Constituição eleva a moralidade administrativa à qualidade de princípio basilar, a ser obedecido pela administração pública direta e indireta de qualquer dos Poderes da União, dos Estados, do Distrito Federal e dos Municípios.

2 Nos termos do art. 37, $\S 4^{\circ}$ da Constituição Federal, "os atos de improbidade administrativa importarão a suspensão dos direitos políticos, a perda da função pública, a indisponibilidade dos bens e o ressarcimento ao erário, na forma e gradação previstas em lei, sem prejuízo da ação penal cabível”.

3 Como se vê da exposição de motivos, o projeto de lei, proposto pelo Poder Executivo, na pessoa do então Ministro da Justiça, Jarbas Passarinho, tinha por objetivo responder ao anseio popular de combate à corrupção e transmitir à sociedade a preocupação do governo federal com a questão. A íntegra da exposição de motivos está disponível no site da Câmara dos Deputados, através do link http: / / www2 .camara.leg.br/ legin/fed/lei/1992/lei-8429-2-junho-1992-357452-exposicaodemotivos-149644-pl.html. Acesso em: 16 set. 2019. 
Grande parte da doutrina posicionou-se no sentido de que não se poderia configurar improbidade administrativa sem a demonstração de dolo ou culpa por parte do agente. Nesse sentido, argumenta-se que, ainda que não se trate de norma penal, por se tratar de atuação sancionatória por parte do Estado, a necessária demonstração do elemento subjetivo emergiria como uma garantia a ser assegurada também no campo das improbidades administrativas (FACCHINI, 2011, p. 59-60; NEISSER, 2018, p. 66). Bem resume este posicionamento a colocação de Osório (2018, p. 254), para quem

não se pode dissociar o ato ímprobo do processo de adequação típica e do reconhecimento da culpabilidade constitucional, aquela da qual dolo e culpa derivam diretamente. A responsabilidade subjetiva, no bojo do tipo proibitivo, e inerente a improbidade administrativa, sendo exigíveis o dolo ou a culpa grave, embora haja silêncio da LGIA sobre o assunto.

De outro lado, houve quem se posicionasse no sentido de que a configuração da improbidade administrativa por lesão a princípios administrativos, na forma do artigo 11 da Lei n. 8.429/1992, não exige a comprovação de que o agente atuou com dolo ou culpa, bastando a ilicitude ou a imoralidade (JURUENA e LEAL, 2014, p. 281-282), mormente por se tratar de ação de cunho cível, âmbito do direito que, cada vez mais, se dissocia do elemento subjetivo. Desse modo, o argumento vai no sentido de que não seria caso de transportar a forma como o Direito Penal trata o sancionamento das condutas para o campo das improbidades, bastando a demonstração de ato potencialmente lesivo e de intolerável incompetência por parte do agente público (SANTOS, 2011, p. 5).

No Superior Tribunal de Justiça (STJ), essa controvérsia traduziu-se em uma relevante discordância entre a Primeira e a Segunda Turma. A Primeira Turma vinha manifestando o entendimento de que o silêncio da lei afasta as condutas culposas dos atos de improbidade sancionados pelos artigos $9^{\circ}$ e 11 da Lei n. 8.429/1992, por entender que a técnica de elaboração da lei de improbidade assemelha-se à técnica penal, na qual, com exceção dos casos expressos em lei, a punição é reservada aos crimes praticados dolosamente. ${ }^{4}$ Por sua vez, a

4 Nesse sentido, veja-se o REsp 604.151/RS (Rel. Min. José Delgado, Primeira Turma, julgado em $25 / 04 / 2006$ ), de cuja ementa consta que "tanto a doutrina quanto a jurisprudência do STJ associam a improbidade administrativa a noção de desonestidade, de má-fé do agente público. Somente em hipóteses excepcionais, por força de inequívoca disposição legal, e que se admite a configuração de improbidade por ato culposo (Lei n. 8.429/1992, art. 10). O enquadramento nas previsões dos arts. $9^{\circ}$ e 11 da Lei de Improbidade, portanto, não pode prescindir do reconhecimento de conduta dolosa”. Da mesma maneira, no REsp 734.984/SP (Rel. Min. José Delgado, Primeira Turma, julgado em 18/12/2007), restou consignado que "o ato de improbidade, na sua caracterização, como de regra, exige elemento subjetivo doloso, à luz da natureza sancionatória da Lei de Improbidade Administrativa”. 
Segunda Turma entendia que o artigo 11 elenca infrações em relação às quais seria desnecessário examinar se o gestor público se comportou com dolo ou culpa, bastando a mera conduta, pois a ofensa ao princípio da moralidade administrativa seria evidente no confronto entre a conduta e a previsão jurídica. ${ }^{\mathbf{5}}$

Mais recentemente, a jurisprudência do STJ consolidou-se no sentido de que é necessária a demonstração do dolo genérico para que seja reconhecida a tipificação da conduta do réu como incurso no artigo 11 da LIA. ${ }^{6}$ Ou seja, para que uma conduta seja caracterizada como ato de improbidade administrativa que atenta contra os princípios da administração pública, em violação aos deveres de honestidade, imparcialidade, legalidade, e lealdade às instituições, é necessária a demonstração de que houve a vontade, ou a assunção consciente do risco, por parte do agente, de concretizar as características objetivas do tipo.

5 Nesse sentido, veja-se o REsp 737.279/PR (Rel. Min. Castro Meira, Segunda Turma, j. 13/05/2008), de cuja ementa consta que "a lesão a princípios administrativos contida no art. 11 da Lei n. 8.429/92, em princípio, não exige dolo ou culpa na conduta do agente nem prova da lesão ao erário público. Basta a simples ilicitude ou imoralidade administrativa para restar configurado o ato de improbidade”. Idêntica à redação que aparece na ementa do REsp n. 988.374/MG (Rel. Min. Castro Meira, Segunda Turma, j. 06/05/2008). Também no REsp n. 488.882/SP (Rel. Min. João Otávio de Noronha, Segunda Turma, j. 17/04/2008), restou consignado que "a contratação de escritório de advocacia quando ausente a singularidade do objeto contatado e a notória especialização do prestador configura patente ilegalidade, enquadrando-se no conceito de improbidade administrativa, nos termos do art. 11, caput, e inciso I, que independe de dano ao erário ou de dolo ou culpa do agente”.

6 A consolidação desse entendimento pelo STJ foi claramente relatada nos autos do REsp n. 875.163/RS (Rel. Min. Mauro Campbell Marques, $1^{a}$ Seção, j. 23/06/2010), quando, em um caso concreto, o tribunal foi chamado a esclarecer a divergência de entendimentos entre as turmas. Na oportunidade, decidiu: “2. O tema central do presente recurso esta limitado a análise da necessidade da presença de elemento subjetivo para a configuração de ato de improbidade administrativa por violação de princípios da Administração Pública, previsto no art. 11 da Lei 8.429/92.

Efetivamente, as Turmas de Direito Público desta Corte Superior divergiam sobre o tema, pois a Primeira Turma entendia ser indispensável a demonstração de conduta dolosa para a tipificação do referido ato de improbidade administrativa, enquanto a Segunda Turma exigia para a configuração a mera violação dos princípios da Administração Pública, independentemente da existência do elemento subjetivo.

3. Entretanto, no julgamento do REsp 765.212/AC (Rel. Min. Herman Benjamin, DJe de 23.6.2010), a Segunda Turma modificou o seu entendimento, no mesmo sentido da orientação da Primeira Turma, a fim de afastar a possibilidade de responsabilidade objetiva para a configuração de ato de improbidade administrativa. 4. Assim, o STJ pacificou o entendimento no sentido de que, para a configuração do ato de improbidade administrativa previsto no art. 11 da Lei 8.429/92, e necessária a presença de conduta dolosa, não sendo admitida a atribuição de responsabilidade objetiva em sede de improbidade administrativa.

5. Ademais, também restou consolidada a orientação de que somente a modalidade dolosa e comum a todos os tipos de improbidade administrativa, especificamente os atos que importem enriquecimento ilícito (art. $9^{\circ}$ ), causem prejuízo ao erário (art. 10) e atentem contra os princípios da administração pública (art. 11), e que a modalidade culposa somente incide por ato que cause lesão ao erário (art. 10 da LIA)”. 
Foi ao julgar o REsp n. 765.212/ AC, ${ }^{7}$ que a questão foi debatida com mais profundidade teórica pelos ministros da Segunda Turma do STJ. O recuso foi interposto pelo Ministério Público do Estado do Acre, no bojo de uma ação ajuizada contra um ex-prefeito e uma ex-secretária municipal da cidade de Senador Guiomard, em razão de as suas imagens terem sido veiculadas em uma propaganda institucional da prefeitura.

Ao apreciar o caso, o Tribunal de Justiça do Acre entendeu pela ausência de comprovação do dolo dos agentes políticos, mas a decisão foi reformada pelo STJ, que condenou tanto o ex-prefeito como a ex-secretária por se utilizarem da propaganda institucional para promoção pessoal. Para o Tribunal, os agentes incorreram em violação dos deveres de honestidade, imparcialidade e legalidade, atentando dolosamente contra os princípios da moralidade administrativa, da impessoalidade e da legalidade.

E, embora a decisão final tenha sido registrada como unânime e os ministros concordem com a prática de ato de improbidade administrativa no caso concreto analisado, ao analisar os votos proferidos, é interessante notar que as suas fundamentações não são idênticas. Ao debater a presença do dolo no caso submetido a julgamento, os ministros deparam-se com a necessidade de lidar com os conceitos de "intenção" e "vontade", e trazem argumentos que partem de pressupostos teóricos radicalmente distintos acerca da ação humana, que merecem atenção especial.

O presente artigo pretende, assim, evidenciar essas diferenças teóricas mais profundas que, embora não tenham sido expressamente abordadas naquela oportunidade, não devem ser ignoradas se se pretende uma aplicação racional e inteligível da LIA. Nesse sentido, será empreendido um estudo do caso (YIN, 2010) do REsp n. 765.212 / AC, com vistas a avaliar a coerência interna dos argumentos trazidos pelos ministros em seus votos, bem como a forma pela qual os conceitos de culpa, dolo e má-fé extraídos da dogmática jurídica foram empregados.

Ademais, explicitando as razões pelas quais a investigação sobre a presença do elemento subjetivo nos casos concretos de improbidade administrativa depende de uma compreensão filosófica sólida sobre o agir humano, o artigo propõe que o debate jurisprudencial travado no caso em análise poderia ser enriquecido a partir de um resgate teórico da noção aristotélica de razão prática. ${ }^{8}$ Com base sobretudo nas ideias de autores contemporâneos da filosofia

$7 \quad$ STJ, Segunda Turma, Rel. Min. Herman Benjamin, j. 02/03/2010, DJe: 23/06/2010.

8 Nos termos da tradição filosófica clássica aristotélica, a razão prática pode ser entendida como a mente funcionando dirigida a uma obra. A virtude intelectual da sabedoria prática (phronesis, prudentia) pode ser definida como um conjunto de habilidades e faculdades (como o senso comum, a imaginação, a capacidade de conjecturar e a capacidade de memorizar) que permite ao agente organizar a sua percepção do mundo em unidades de sentido compartilhados socialmente, permitindo-lhe escolher os meios adequados para atingir determinados fins que podem ser discursivamente justificados em função de um modo de vida. A este respeito, ver Michelon (2010) e Finnis (2005). 
moral, apresenta-se um ferramental teórico que pode ser útil para a avaliação das condutas humanas ao compreendê-las como a eleição voluntária de meios em direção a fins que devem ser justificáveis socialmente, em função de valores protegidos pela coletividade.

\section{IMPROBIDADE: A ILEGALIDADE QUALIFICADA PELA MÁ-FÉ}

Como se adiantou, o ordenamento jurídico brasileiro protege a moralidade administrativa. A este respeito, importa, inicialmente, explicitar o que se entende por moralidade administrativa. Como bem aponta Giacomuzzi (2002, p. 291-293) ao fazer uma revisão histórica do conceito na doutrina jurídica brasileira,

impera sobremodo um desconfortável senso comum na doutrina pátria quando se trata de abordar o assunto da vinculação entre Moral e Direito sob o aspecto da moralidade administrativa. [...] A moralidade é vinculada ora à legalidade, ora à igualdade, ora ao interesse público, ora ao desvio de poder, ora à proporcionalidade. E tudo e nada ao mesmo tempo.

Em uma proposta de sistematização dogmática do conceito, o autor sugere a existência de duas "moralidades" distintas, protegidas pelo ordenamento jurídico brasileiro. A primeira delas, prevista no art. $5^{\circ}$ da CF/1988, refere-se à legalidade interna do ato praticado pelo agente público, em relação ao qual seria necessário perquirir eventual desvio de finalidade. Ou seja, o controle de legalidade do ato pode dar-se a partir da sua legalidade externa - em razão da existência de vícios de incompetência, procedimento ou forma - ou da sua legalidade interna - diante de vícios de conteúdo, de motivos e de intenção. E, justamente, ao controlar a legalidade interna do ato é que se investigam os desvios de finalidade, como forma de proteção da moralidade (GIACOMUZZI, 2002, p. 298-299).

Já a segunda moralidade está prevista no art. 37 da CF/1988 e tem por função veicular ao Direito Público o princípio da boa-fé, que é tanto objetiva, consubstanciada na proteção da confiança, quanto subjetiva, materializada na vedação e na repressão da improbidade administrativa (GIACOMUZZI, 2002, p. 300-301).

A distinção é útil, pois fornece uma base conceitual mais sólida para a compreensão da LIA como integrante de um sistema normativo de proteção da moralidade administrativa, por meio do controle da boa-fé subjetiva daqueles que integram ou contratam com o Poder Público.

Esse sistema normativo é complementado pelas Leis da Ação Popular (Lei n. 4.717/1965) e da Ação Civil Pública (Lei n. 7.347/1985), que preveem instrumentos processuais aptos a buscar a reparação dos eventuais danos causados à coletividade e a anulação de atos administrativos danosos ou ilícitos.

As sanções associadas às condutas tidas como ímprobas têm cunho punitivo e revestem-se de especial gravidade, podendo resultar até mesmo na suspensão dos direitos políticos do 
cidadão, que fica, portanto, impedido de votar e ser votado. Em razão disso, parte da doutrina administrativista vem aproximando esse conjunto de normas do Direito Penal, informado pela necessidade de se garantir ao acusado o respeito aos seus direitos fundamentais e as garantias de ampla defesa e contraditório (GARCIA e ALVES, 2014, p. 431; LOBO DA COSTA, 2014, p. 112; NEISSER, 2018, p. 103-104).

Um dos princípios norteadores do Direito Penal que, de maneira geral, vem se admitindo ter aplicação no campo da improbidade administrativa, por seu caráter sancionador, e o princípio da culpabilidade, segundo o qual a punição de qualquer pessoa depende da sua atuação com dolo ou culpa. Assim, a LIA prevê apenas hipóteses de responsabilidade subjetiva, sendo impossível a responsabilização objetiva do agente público (NEISSER, 2018, p. 71; CARVALHO FILHO, 2018, p. 1.157; JUSTEN FILHO, 2016, p. 948-949; DI PIETRO, 2017, p. 1.023-1.024). Assim, não bastaria a existência do nexo causal entre o ato e o resultado delitivo, sendo fundamental o exame da subjetividade do agente:

No direito moderno, assume ares de dogma a concepção de que não é admissível a imputatio iuris de um resultado danoso sem um fato de ligação psíquica que a ele vincule o agente. Ressalvados os casos em que a responsabilidade objetiva esteja expressamente prevista no ordenamento jurídico, é insuficiente a mera demonstração do vínculo causal objetivo entre a conduta do agente e o resultado lesivo. Inexistindo um vínculo subjetivo unindo o agente à conduta, e esta ao resultado, não será possível demonstrar “o menosprezo ou descaso pela ordem jurídica e, portanto, a censurabilidade que justifica a punição (malum passionais ob malum actionis)”. (GARCIA e ALVES, 2014, p. 432)

Todavia, ao contrário do que se verifica no campo do Direito Penal, a doutrina administrativista no Brasil, de maneira geral, ${ }^{9}$ não se aprofunda no estudo dos elementos constitutivos do elemento subjetivo da improbidade administrativa. Majoritariamente, os autores limitam-se a afirmar que a improbidade administrativa pode ser entendida como a ilegalidade qualificada pela má-fé do agente, sendo absolutamente imprescindível que se perquira pela intenção do agente (GIACOMUZZI, 2013, p. 269). Esse entendimento aparece, frequentemente, reproduzido em decisões judiciais do $\mathrm{STJ}^{10}$ sem maiores considerações acerca

9 Exceção a essa situação é a recente tese de doutorado de Neisser (2018), que aborda especificamente a questão do dolo na improbidade administrativa, tentando propor critérios para a imputação subjetiva na aplicação da Lei n. 8.429/1992.

10 Nesse sentido, vejam-se, a título exemplificativo, os seguintes julgados: “A má-fé, consoante cediço, é premissa do ato ilegal e ímprobo e a ilegalidade só adquire o status de improbidade quando a conduta antijurídica fere os princípios constitucionais da Administração Pública coadjuvados pela má-intenção do administrador” (STJ, REsp n. 1.112.062/SP, Rel. Min. Luiz Fux, Primeira Turma, j. 22/09/2009); “A jurisprudência 
dos elementos e critérios de imputação subjetiva que devem ser empregados nos casos de improbidade. A dificuldade que se coloca, no entanto, é como individualizar o elemento subjetivo na análise de um caso concreto.

\section{A (IMPOSSÍVEL) TESE DA VOLUNTARIEDAdE DA CONDUTA}

O caso que consolidou o entendimento do STJ acerca da necessidade de demonstração do elemento subjetivo para que se possa atribuir ao agente a prática de ato de improbidade administrativa que viola os princípios da Administração Pública foi o REsp n. 765.212/AC. ${ }^{11}$ Cuida-se de uma ação de improbidade administrativa ajuizada pelo Ministério Público do Estado do Acre contra um ex-prefeito e uma ex-secretária municipal de uma cidade do interior do Estado, em razão da veiculação de imagens dos agentes políticos em um comercial da prefeitura, com duração de 45 segundos, intitulado "Senador Guiomard - A Cidade do Novo Milênio", a qual custou aos cofres públicos R\$2.950,00 (dois mil, novecentos e cinquenta reais).

Os agentes públicos foram acusados de se utilizar de propaganda institucional para se promoverem pessoalmente e, embora tenham sido, inicialmente, absolvidos pelo Tribunal de Justiça do Acre, que entendeu pela falta de atuação dolosa, a decisão foi revertida no STJ, que os condenou por improbidade administrativa, nos termos do art. 11 da Lei n. 8.429/1992, por entender que os agentes violaram os deveres de honestidade, imparcialidade e legalidade, atentando dolosamente contra os princípios da moralidade administrativa, da impessoalidade e da legalidade.

Em seu voto no REsp n. 765.212, o Rel. Min. Herman Benjamin, defendeu inicialmente a tese da voluntariedade da conduta. Nesse sentido, afirmou que

[...] quem desrespeita um princípio constitucional da magnitude da impessoalidade e o faz por livre e espontânea vontade, pouco há que se perquirir acerca de um elemento subjetivo complementar, muito mais afeito à consecução do resultado do que propriamente ao cometimento da infração em si mesma [...] Em síntese, quer me parecer que o elemento

do STJ, inclusive de sua Corte Especial, no sentido de que 'não se pode confundir improbidade com simples ilegalidade. A improbidade é ilegalidade tipificada e qualificada pelo elemento subjetivo da conduta do agente. Por isso mesmo, a jurisprudência do STJ considera indispensável, para a caracterização de improbidade, que a conduta do agente seja dolosa, para a tipificação das condutas descritas nos artigos $9^{\circ}$ e 11 da Lei n. 8.429/1992, ou pelo menos eivada de culpa grave, nas do artigo 10' (AIA 30/AM, Corte Especial, DJe de 27/09/2011)" (STJ, AgRg no AREsp n. 184.147/RN, Rel. Min. Humberto Martins, Segunda Turma, j. 14/08/2012).

STJ, Segunda Turma, Rel. Min. Herman Benjamin, j. 02 mar. 2010, DJe: 23/06/2010. 
subjetivo, no caso, reside na simples intenção dos agentes ( $=$ voluntariedade) de praticarem o ato, in casu com a identificação pessoal em propaganda governamental, a custa do erário público. A promoção pessoal foi realizada por ato voluntário, desvirtuando a finalidade estrita da propaganda pública, a saber, a educação, a informação e a orientação social. É desnecessário, nesse contexto, perquirir se os recorridos agiram com intuito específico de violar os princípios administrativos e a norma constitucional citada alhures. (p. 17)

Para o ministro, olvidar um princípio constitucional de tamanha relevância simplesmente não seria tolerável, bastando que a conduta do agente fosse de livre e espontânea vontade para que se caracterizasse a improbidade administrativa. Segundo esse entendimento, bastaria o agente querer praticar o ato e que o ato viole efetivamente os princípios da Administração Pública para que se configure improbidade. Não se exige que o agente tenha a intenção específica de violar princípios ou que tenha assumido conscientemente o risco de fazê-lo, mas apenas a intenção de praticar o ato em si.

Segundo esse raciocínio, se o agente público assina um contrato administrativo que não foi precedido do devido processo licitatório, porque foi desrespeitado o prazo mínimo de publicidade do edital, comete improbidade - ainda que ele não tivesse conhecimento daquelas falhas ou não tivesse intenção de beneficiar a empresa contratada. A vontade de assinar o documento poderia ser enquadrada como dolo, pouco importando se a inobservância do prazo de publicidade tenha sido um erro do qual o agente não tivesse conhecimento ou, ainda, que não tivesse a intenção de restringir a competitividade da licitação.

Ocorre que, a menos que se esteja diante de um caso de coação, se um documento foi assinado, é porque se quis assinar; se um edital foi publicado, é porque se quis publicar; se a filmagem e a veiculação de uma propaganda institucional foram autorizadas, é porque se quis autorizar. O grande problema desse argumento, para o Ministro Mauro Campbell Marques, é que ele confunde vontade com voluntariedade. Como afirma o ministro em seu voto-vista:

voluntariedade [...] não se confunde com vontade. A vontade necessariamente pressupõe uma conduta com resultado querido. Novamente com Luiz Regis Prado, citandoWelzel: [...], 'a voluntariedade significa que um movimento corporal e suas consequências podem ser conduzidos a algum ato voluntário, sendo indiferente quais consequências queria produzir o autor.' Isso quer dizer que a voluntariedade se caracteriza pela simples inervação muscular que põe em andamento um processo de natureza causal. De outro lado, a vontade tem conteúdo próprio inerente ao comportamento humano, e diz respeito a um resultado querido. (...) O conceito de voluntariedade deixa de fora inúmeras situações, nas quais, apesar de haver voluntariedade na conduta, não se poderá caracterizar a improbidade. (p. 28, grifo nosso) 
De fato, se toda ação humana é orientada a determinados fins ${ }^{12}$ ao excluir a análise da finalidade da ação, a tese da voluntariedade termina por admitir a responsabilização objetiva do agente público. Entender que o dolo se extrai da intenção de praticar um determinado ato, pouco importando o que o agente conhecia à época e o que objetivava com aquele ato, é permitir, em alguns casos, a equiparação da improbidade com a mera ilegalidade, o que contraria a própria jurisprudência do STJ, que reiteradamente vem decidindo que a improbidade é a ilegalidade qualificada pela má-fé e que o objetivo da legislação é o de punir, exclusivamente, o agente corrupto e desleal e não o incompetente ou o inábil. ${ }^{13}$

A tese da voluntariedade da conduta foi rebatida pelo Ministro Mauro Campbell Marques, que, a partir de uma reconstrução teórica, sustentou que, no campo do Direito Administrativo Sancionador, aplica-se o princípio da culpabilidade, segundo o qual a punição de qualquer pessoa depende da sua atuação com dolo ou culpa, admitindo-se apenas excepcionalmente a responsabilização objetiva no âmbito não sancionatório do Direito Civil. Nesse sentido, defendeu que não basta o nexo causal entre o ato e o resultado delitivo, sendo fundamental a subjetividade, vale dizer, que a ação seja orientada a um resultado querido, diferenciando-se a voluntariedade da vontade.

O entendimento esposado pelo Ministro Mauro Campbell Marques, contrário à tese da voluntariedade da conduta, prevaleceu na corte, que acatou a necessidade de se perquirir pelo

12 Também nos termos do voto do Ministro Mauro Campbell: "[...] toda ação humana é orientada a determinado fim. A finalidade, portanto, não é uma adjetivação do comportamento humano, mas, ao contrário, é o seu real elemento constitutivo. O homem ao agir antecipa os fins, seleciona os meios e considera todos os possíveis resultados (efeitos desejados e concomitantes). Para que a tipicidade possa considerar este modelo de ação, é imprescindível que integre em seu seio as modalidades dolo e culpa. Não há tipo sem dolo e culpa, pois ou a tipicidade é dolosa ou a tipicidade é culposa" (p. 29).

13 Nesse sentido, vejam-se, a título de exemplo, os seguintes julgados: "Para configuração do ato de improbidade administrativa previsto no art. 11 da Lei n. 8.429/1992, este Tribunal Superior exige, ainda, a nota especial da má-fé, pois a Lei de Improbidade Administrativa não visa punir meras irregularidades ou o inábil, mas sim o desonesto, o corrupto, aquele desprovido de lealdade e boa-fé” (STJ, AgInt no AREsp n. 838.141/MT, Ministro Og Fernandes, Segunda Turma, j. 27/11/2018).

"Para a correta fundamentação da condenação por improbidade administrativa, é imprescindível, além da subsunção do fato à norma, estar caracterizada a presença do elemento subjetivo. A razão para tanto é que a Lei de Improbidade Administrativa não visa punir o inábil, mas sim o desonesto, o corrupto, aquele desprovido de lealdade e boa-fé. [...] Precedentes: AgRg no REsp 1.500.812/SE, Rel. Ministro Mauro Campbell Marques, Segunda Turma, DJe: 28/5/2015; REsp 1.512.047/PE, Rel. Ministro Herman Benjamin, Segunda Turma, DJe 30/6/2015; AgRg no REsp 1.397.590/CE, Rel. Ministra Assusete Magalhães, Segunda Turma, DJe 5/3/2015; AgRg no AREsp 532.421/PE, Rel. Ministro Humberto Martins, Segunda Turma, DJe 28/8/2014” (REsp n. 1.508.169/PR, Rel. Min. Herman Benjamin, Segunda Turma, j. 13/12/2016, DJe: 19/12/2016). "É sabido que meras irregularidades não sujeitam o agente às sanções da Lei 8.429/92” (STJ, AgInt no AREsp n. 569385/SE, Rel. Min. Og Fernandes, Segunda Turma, j. 02 / 10/2018). 
elemento subjetivo (intenção e vontade) para que se possa falar em punição por ato de improbidade administrativa. A definição das características do elemento subjetivo a ser demonstrado, no entanto, foi alvo de divergência e impõe dificuldades ao intérprete que merecem ser abordadas com maior profundidade.

\section{A vontade e o elemento subJetivo: CUlPa, DOlO E mÁ-FÉ}

Uma vez superada a tese da voluntariedade da conduta, tendo os ministros acordado ser impossível a incidência das sanções previstas na LIA sem que se fale na vontade do agente de cometer o ato ilícito, o tribunal passou a debater, então, qual seria o elemento subjetivo necessário à configuração do ato ímprobo.

A primeira questão debatida, a este respeito, foi sobre a possibilidade, ou não, de punição da ação culposa nos casos enquadrados no artigo 11 da norma, que diz respeito à violação dos deveres impostos pelos princípios que regem a Administração Pública. Com efeito, o artigo $10 \mathrm{da}$ lei, relativo aos atos de improbidade que causam prejuízo ao erário, faz referência expressa ao elemento subjetivo do agente, expressamente abarcando qualquer ação ou omissão dolosa ou culposa. Dos artigos 9 e 11, no entanto, nada consta no que tange ao elemento subjetivo exigido para a configuração de ato de improbidade, razão pela qual alguns autores afirmam que na LIA, assim como na legislação penal, a referência expressa à modalidade culposa seria necessária para que se pudesse falar em improbidade culposa (CARVALHO FILHO, 2018, p. 1.163).

Este foi, justamente, o entendimento prevalecente na corte. Ainda assim, o Ministro Humberto Martins ressalvou, em seu voto, o seu entendimento pessoal no sentido de que o ato de improbidade administrativa poderia ser caracterizado tanto em caso de dolo quanto em caso de culpa. Para ele, o fato de o legislador ter feito menção expressa, no art. 10, à ação ou omissão dolosa ou culposa não permite concluir que o silêncio da lei quanto ao elemento subjetivo, no art. 11, exclui a possibilidade de infração por culpa. Isso porque a linguagem da LIA seria distinta da linguagem do Direito Penal. Neste, geralmente, a configuração do ilícito depende de ato doloso, de modo que se exige menção à culpa no tipo, por se tratar dos casos excepcionais. Já no Direito Administrativo Sancionador, a culpa não assume caráter excepcional e não importa para a configuração do ilícito, senão apenas para a dosimetria da sanção. Ademais, no seu entender, a Lei n. 8.429/1992 não reprova apenas o agente desonesto, que age com má-fé, mas também o que deixa de agir de forma diligente no desempenho da função para a qual foi investido, punindo a grave negligência, a inabilitação para o serviço público e os erros intoleráveis.

Em sentido contrário, no entanto, foi o do voto do Ministro Mauro Campbell Marques, que sustentou a impossibilidade de configuração de ato de improbidade administrativa nos termos do artigo 11 da Lei n. 8.429/1992 na modalidade culposa, por entender que a lei alcança o administrador desonesto, não o inábil. Para o ministro, as graves sanções cominadas 
pelo dispositivo legal em comento são atraídas apenas pela atuação dolosa, enquanto as condutas culposas podem - e devem - ser punidas em outras esferas de responsabilização, pela via do controle interno e externo da Administração Pública, seja no bojo dos Tribunais de Contas, de processos administrativos disciplinares ou em procedimentos movidos pelo Ministério Público, pelo Conselho Nacional de Justiça ou, ainda, de natureza fiscal. Sustentou, dessa maneira, ser imprescindível a violação intencional dos deveres de honestidade, lealdade e retidão no trato dos assuntos públicos, uma vez que seria inimaginável que alguém pudesse ser desleal ou desonesto sem querer.

É notável que a divergência entre os ministros se fundamenta, em última análise, em uma discordância essencial acerca do que a LIA representa, dos seus objetivos, fundamentos e alcance. Por essa razão, é surpreendente que os ministros, ainda assim, tenham conseguido deixar essa questão de lado para alcançar um entendimento comum quanto ao elemento subjetivo da improbidade. ${ }^{14} \mathrm{E}$, de fato, tomando por base fundamentos teóricos retirados do Direito Penal, o tribunal acordou ser necessário, para a configuração do ato de improbidade administrativa nos termos do artigo 11 da Lei n. 8.429/1992, a demonstração de dolo genérico.

Neste passo, importa trazer da doutrina penalista alguns conceitos fundamentais. O dolo, para este ramo do Direito, costuma ser definido como a consciência e a vontade de realização dos elementos objetivos do tipo de injusto doloso. Nesses termos, age dolosamente o agente que conhece e quer a realização dos elementos previstos no tipo legal do delito, sejam eles os elementos descritivos - que delimitam objetos, seres e ações perceptíveis pelos sentidos -, sejam os elementos normativos - que exigem um juízo de valor para o seu conhecimento, muitas vezes expressos em termos como “indevidamente”, “sem justa causa”, etc. (PRADO, 2014, p. 300).

A doutrina penal tradicional costuma classificar o dolo, que pode ser diferenciado em dolo direito, indireto ou, ainda, em dolo genérico ou específico. O dolo direito (ou dolo de primeiro grau) corresponde à vontade do agente dirigida especificamente à produção do resultado típico, abrangendo os meios utilizados para tanto. Já o dolo indireto (ou dolo eventual)

O entendimento comum foi firmado não com base em fundamentos teóricos, mas a partir de considerações pragmáticas acerca das implicações do posicionamento eventualmente adotado pela Corte para a efetividade da LIA. De fato, em seu voto, o Ministro Humberto Martins ressaltou que, embora continuasse acreditando ser tecnicamente válida e mais correta a linha de argumentação anteriormente exposta e defendida por ele, no sentido da possibilidade de configuração de ato de improbidade administrativa na modalidade culposa para o artigo 11 da Lei n. 8.429/1992, reposicionou-se no sentido de se filiar ao entendimento da maioria, por entender que, "no terreno pragmático, a exigência de dolo genérico, direto ou eventual, para o reconhecimento da infração ao art. 11, não trará maiores prejuízos à repressão à imoralidade administrativa”. Nesse sentido, ao que tudo indica, havia uma preocupação com o risco de que a exigência do elemento subjetivo doloso implicasse dificuldades probatórias aptas a conduzir à impunidade dos réus em ações de improbidade administrativa. 
é a vontade do agente dirigida a um resultado determinado, porém vislumbrando a possibilidade de ocorrência de um segundo resultado, não desejado, mas admitido (NUCCI, 2018, p. 191-192). Ou seja, no primeiro, o agente quer o resultado proibido pela lei; no segundo, assume o risco de produzi-lo. Tanto o dolo direito como o indireto foram admitidos pelo STJ para a configuração de ato de improbidade administrativa.

O dolo também pode ser classificado como genérico ou específico. O dolo genérico, que foi reputado essencial para a configuração de ato de improbidade pelos ministros do STJ, no âmbito penal é definido como "a vontade de praticar a conduta típica, sem qualquer finalidade especial” (NUCCI, 2018, p. 190), contrapondo-se ao dolo específico, que seria vontade de praticar a conduta típica, adicionada de uma especial finalidade. Por exemplo, "nos crimes contra a honra, não bastaria ao agente divulgar fato ofensivo à reputação de alguém para se configurar a difamação, sendo indispensável que agisse com dolo específico, ou seja, a especial intenção de difamar, de conspurcar a reputação da vítima” (NUCCI, 2018, p. 190).

Assim, fazendo referência a estes conceitos do campo penal, os ministros consolidaram entendimento no sentido de exigir a demonstração de dolo genérico, direito ou eventual, para a configuração de improbidade administrativa nos termos do artigo 11 da Lei n. 8.429/1992. Os contornos desse conceito de dolo que pode ser extraído dos votos dos ministros, no entanto, não são exatamente claros quando transpostos para o caso concreto.

De um lado, o voto do Ministro Mauro Campbell Marques consignou que o dolo compreende necessariamente o conhecimento e o querer (vontade) e que seria necessário que o agente conhecesse a norma proibitiva que está a infringir, bem como que tenha desejado infringi-la sem, no entanto, que fosse necessário buscar qualquer finalidade a mais, além do próprio objetivo reprovável. Veja-se:

não ha qualquer elemento subjetivo especial na tipologia, vale dizer, não é preciso que, para caracterizar a improbidade, o agente busque qualquer finalidade a mais além do próprio objetivo reprovável.

Uma comparação simples ajudará a entender a extensão da assertiva anterior. O art. 159 do $\mathrm{CP}$ diz que é crime sujeito à pena de reclusão "[s]equestrar pessoa com o fim de obter, para si ou para outrem, qualquer vantagem, como condição ou preço do resgate”. A locução "com o fim de" caracteriza um elemento subjetivo especial do tipo, uma finalidade a mais, ou, como se diz na doutrina penal, um especial fim de agir. É verdade que, para caracterizar a extorsão mediante sequestro, é desnecessário o alcance dessa finalidade, mas ela integra o tipo.

Lado a lado arts. 159 do CP e 11 da LIA, fica nítido que para este último é despicienda a busca por uma finalidade diferente da violação aos deveres nele colocados. É por isso que também não é correto exigir a presença de dolo específico. Basta o dolo lato sensu (direto - resultado querido e aderente a ação - ou eventual - risco de produção do resultado). (p. 34, grifo nosso) 
Nesse sentido, o ministro parece indicar que a verificação do dolo independe da comprovação de uma intenção escusa específica na conduta dos réus em uma ação de improbidade, como de enriquecimento indevido ou favorecimento de terceiro, por exemplo, bastando a intenção de violar um princípio regente da Administração Pública que, sabidamente, deveria ser observado naquele caso concreto.

Assim, ao decidir o caso concreto, o ministro afirmou que os gestores municipais não poderiam alegar desconhecer a norma constitucional que veda a veiculação de propagandas para promoção pessoal. Eles sabiam (ou deveriam saber) que, havendo veiculação das suas imagens na campanha publicitária, poderia haver caracterização de merchandising pessoal e, ainda assim, anuíram com a sua veiculação, de modo que se pode concluir que agiram com dolo genérico e eventual.

Já o Ministro Humberto Martins, em seu voto, sustentou que o dolo reside na simples consciência e vontade de praticar determinada conduta, comissiva ou omissiva, que não se coadune com os princípios administrativos e com os deveres de honestidade, imparcialidade, legalidade e lealdade às instituições, pouco importando se o agente atua com intenção específica de violar a lei ou com outra especial finalidade. O ministro aproxima o dolo genérico, novamente, da tese da voluntariedade da conduta, ao exemplificar que, em caso de contratação de servidor sem concurso público, o dolo estaria configurado se for manifesta a vontade de realizar conduta contrária ao dever de legalidade, pois é inequívoca a obrigatoriedade do certame (art. 37, II, da Constituição da República).

Assim, ao decidir o caso concreto, afirmou que:

A promoção pessoal foi realizada por ato voluntário, desvirtuando a finalidade estrita da propaganda pública, [...] o que é suficiente a evidenciar a imoralidade. Não constitui erro escusável, nem tolerável irregularidade, olvidar um princípio constitucional da magnitude da impessoalidade e a vedação contida no art. 37, § 1o, da Constituição da República.

A regra do ordenamento jurídico brasileiro é tão simples como conhecida de todos: o administrador que quiser fazer promoção pessoal pode fazê-lo, respeitados os limites da legislação eleitoral, desde que às suas próprias expensas. [...]

O dolo está configurado pela manifesta vontade de realizar conduta contrária aos deveres de honestidade e legalidade, e aos princípios da moralidade administrativa e da impessoalidade. (p. 16-17)

Verifica-se, portanto, uma divergência entre os ministros quanto aos contornos do dolo genérico que se pretendeu definir: se, por um lado, o Ministro Humberto Martins sustenta que o dolo seria natural, correspondente à simples vontade de fazer algo, não importando a consciência da ilicitude, por outro lado, o voto do Ministro Mauro Campbell Marques parece basear-se na ideia de que o dolo envolve os elementos normativos do tipo proibitivo, de modo que, ainda que não se exija comprovação de que o agente visou enriquecer ou se favorecer, 
ainda assim seria o caso de indagar se tinha consciência (ou deveria ter) de que estaria a violar um princípio regente da Administração Pública ao agir da forma como agiu.

Cuida-se da diferença entre presumir ou não o dolo como uma decorrência natural da mera violação normativa. De fato, admitir o dolo eventual e genérico ao mesmo tempo em que se espera do agente público que detenha um conhecimento excessivamente amplo acerca da aplicação concreta de todas as regras que regem a Administração Pública torna a sua responsabilização praticamente objetiva, pois

cai-se em um círculo vicioso e tautológico, que pode ser compreendido pela enumeração adiante exposta:

a. Ao agir de forma contrária a uma lei (ou ao entendimento que dela tem o órgão que futuramente analisará eventual ação por ato de improbidade administrativa), o agente público viola o dever de observar os princípios que regem a Administração Pública;

b. Mesmo que não se tenha indicação de que a vontade do autor se dirigiu a uma finalidade específica, era certo que competia a ele conhecer os ditames da lei (ou da interpretação que dela tem o órgão julgador);

c. Assim, no mínimo, o agente público deveria saber que o resultado da ação poderia acarretar o fim contrário à norma.

Dificilmente se pode imaginar hipótese em que o acusado, nestas circunstâncias, logre desvencilhar-se da teia em que enredado. A combinação do dolo eventual, como delineado pelo Superior Tribunal de Justiça, com a presunção praticamente absoluta de conhecimento, torna impossível tal desiderato. (NEISSER, 2018, p. 73-74)

Assim é que, sem expor com clareza, retorna-se à responsabilização objetiva do agente, sob a aparência de aceitação da exigência do dolo.

Do ponto de vista teórico, parece possível seguir o caminho trilhado pelo STJ na adoção de uma concepção de dolo que assume não ser necessária a intenção de causar dano ou prejuízo, bastando que se infrinja de maneira consciente e voluntária, um dever jurídico que pesa sobre o agente. E, nesse sentido, a discussão recai, justamente, sobre o agir consciente, sobre o elemento intelectivo e sobre as circunstâncias nas quais é possível deduzir que o agente tinha consciência de que, ao agir de determinado modo, violaria norma proibitiva - o que, certamente, não se confunde com o conhecimento em tese das normas legais que regulam a Administração Pública. Diante disso, faz-se imprescindível o debate sobre os critérios a serem empregados para o fim de atribuir a determinado agente público a presunção de detenção de determinadas informações (NEISSER, 2018). ${ }^{15}$ Atualmente, no entanto, ainda

15 "A falta de representação de um aspecto da realidade ou a sua apreensão em discrepância com a realidade significam, ao fim e ao cabo, que o agente não detinha, ao momento dos fatos, o conhecimento exigido para 
faltam contornos dogmáticos mais definidos para o conceito de dolo no âmbito das improbidades administrativas.

Outra questão relevante que se coloca quanto ao elemento subjetivo necessário à configuração de ato de improbidade administrativo é que, paralelamente a essa definição de dolo, que se pretende técnica, os ministros do STJ, apoiados em decisões anteriores e no posicionamento majoritário da doutrina, mantêm a exigência de um elemento de desonestidade ou má-fé por parte do autor, sem o qual não há que se falar em ato de improbidade administrativa nos termos dos artigos $9^{\circ}$ e 11 da Lei n. 8.429/1992.

É justamente esse o argumento que aparece no voto do Ministro Mauro Campbell Marques no sentido de que a LIA alcança o administrador desonesto, não o inábil. Ora, essa exigência de uma verdadeira "intenção nefanda", sem dúvida, afasta-se da assertiva dos ministros no sentido de que não seria o caso de perquirir quanto a uma finalidade específica no agir, e de que bastaria o que se denominou dolo genérico (NEISSER, 2018, p. 73).

Em uma tentativa de sistematização conceitual, Neisser (2018, p. 238-241) sustenta que a má-fé não constitui elemento do dolo, mas é condição para a imputação da improbidade administrativa ao sujeito. Assim, para a configuração do dolo, seria desnecessário identificar um intuito específico quando da prática da conduta típica. Todavia, sem que se demonstre que a conduta foi praticada com um estado mental de desonestidade, não há que se falar em improbidade administrativa. ${ }^{16} \mathrm{~A}$ ausência de má-fé funcionaria, assim, como a falta

a imputação do dolo. [...] Uma das circunstâncias que objetivamente podem limitar ou condicionar uma conduta é falta de disponibilidade de informação precisa sobre aquilo acerca do qual deve haver decisão [...]" (NEISSER, 2018, p. 262). Para o autor, tendo em vista que o conhecimento não é aferível de modo empírico, ele poderia ser atribuído em razão (i) da mera vida em sociedade, que permite presumir que cada indivíduo dispõe de conhecimentos mínimos atribuíveis a qualquer pessoa normal, de modo que afastar esse conjunto de conhecimentos mínimos seria ônus de quem alega desconhecimento; (ii) da transmissão prévia de conhecimento realizada de forma apta a mitigar falhas de memória, aumentando a possibilidade de permanência de conteúdos mais relevantes; (iii) de o conhecimento sobre o tema ter sido previamente exteriorizado pelo sujeito (antes, durante ou depois da realização da conduta) em declarações ou atos conclusivos de exteriorização; (iv) de características pessoais do sujeito que permitam lhe atribuir determinados conhecimentos; (v) de comportamento de cegueira deliberada, quando o agente busca distanciar-se propositalmente do ato ímprobo ao delegar a terceiros o dever de conhecimento quando poderia evitar o desconhecimento.

“A confusão entre má-fé e dolo é compreensível, especialmente ante a ausência de uma reflexão acadêmica mais profunda sobre a imputação subjetiva na improbidade administrativa [...]. Ainda que haja notável confusão entre os institutos, chamando de dolo da improbidade aquilo que não o é - a má-fé ou desonestidade do agir -, é inegável que doutrina e jurisprudência, em raro acordo, reconhecem que não se pode falar em improbidade sem a demonstração de que a conduta foi praticada com um estado mental de desonestidade. [...] Entende-se que esse requisito se posta ao lado do dolo, sem com ele se confundir, mas também como condição 
de consciência da antijuridicidade, que exclui a culpabilidade no âmbito penal (NUCCI, 2018 , p. 257). ${ }^{17}$

O elemento subjetivo, nas ações de improbidade administrativa, não se limita, assim, à demonstração do dolo, nos termos da definição pouco precisa que o STJ tentou firmar no caso do REsp n. 765.212, mas abarca também a questão da má-fé, de modo que se torna inescapável que o tema da improbidade administrativa seja abordado a partir de uma compreensão mais abrangente sobre a racionalidade e a inteligibilidade da ação humana.

\section{IMPROBIDADE ADMINISTRATIVA E AÇÃO RACIONAL}

A esta altura, resta claro que, ao indagar sobre o elemento subjetivo para fins de aplicação da LIA, faz-se necessário indagar sobre as razões que expliquem e, eventualmente, justifiquem uma determinada conduta. A vontade e a intenção revelam-se, assim, como os elementos humanos, inescapáveis da ação e sua investigação exige do juiz uma atitude interpretativa, no sentido de compreender as razões pelas quais o agente agiu como agiu. Como explica Lopes (2004, p. 139):

Sentido e propósito são conceitos importantes ao tratar da ação humana. Ao falar de propósito, assumimos que certo comportamento não é o resultado puro e simples de reação cega. Ele envolve alguma escolha ou intenção. Ao falar de sentido pressupomos que a pessoa poderá dar razões para a sua ação. Sentido e propósito ajudam a responder à questão 'por quê'.

Há, aqui, uma distinção que não é suficientemente explorada nos votos dos ministros do STJ, mas que pode ser relevante para a compreensão da questão posta. Cuida-se da distinção entre (i) o comportamento irracional, fruto do reflexo ou da reação cega; (ii) o ato voluntário, vinculado a um propósito e que envolve alguma escolha ou intenção por parte do agente; e (iii) a ação racional, que é aquela vinculada a um sentido, de modo que o agente pode dar

sem a qual não se pode falar em improbidade administrativa. A ausência de má-fé erige-se, assim, como causa de justificação, afastando a antijuridicidade da conduta, como critério negativo, e compondo, em conjunto com o dolo, o elemento subjetivo da improbidade administrativa” (NEISSER, 2018, p. 239-241).

"Sob a ótica do finalismo, a conduta é uma movimentação corpórea, voluntária e consciente, com uma finalidade. Logo, ao agir, o ser humano possui uma finalidade que é analisada desde logo, sob o prisma doloso ou culposo. Para tipificar uma conduta, portanto, a análise do dolo e da culpa já são analisadas quando avaliada a tipicidade. A culpabilidade, por sua vez, é o juízo de reprovabilidade que incide sobre o autor e sobre o ato antijurídico praticado por ele: o autor precisa ser imputável e ter agido com consciência potencial da ilicitude (que é extraída do dolo), em situação na qual era exigível um comportamento conforme o Direito" (NUCCI, 2018, p. 257). 
razões que expliquem e justifiquem sua conduta segundo princípios ou bens que uma dada sociedade elegeu como desejáveis.

A noção de ação racional, nos termos aqui propostos, deriva do conceito de razão prática que, segundo a tradição filosófica aristotélica, consiste em uma virtude intelectual, uma faculdade humana que permite ao agente organizar a sua percepção do mundo em unidades de sentido compartilhados socialmente, de modo que, ao agir, os fins das suas ações são justificados em função de um modo de vida. Da mesma maneira, viabiliza-se a eleição do meio mais adequado para atingir aqueles fins (MICHELON, 2010; FINNIS, 2005).

Se a ação humana é, necessariamente, orientada a fins, a direção da sua conduta, no entanto, decorre de uma escolha. Como explica Grisez (2007, p. 82-83):

[...] o primeiro princípio da razão prática oferece um requisito básico para a ação ao prescrever simplesmente que ela seja intencional, e é à luz deste requisito que os objetos de todas as inclinações se compreendem como bens humanos e se determinam como objetos de busca racional. [...] Já que o fim último específico não lhe é determinado pela natureza, o homem é capaz de assumir o compromisso básico que orienta toda sua vida. A vontade humana naturalmente é não determinada exatamente na medida que o preceito de que o bem deve ser buscado transcende a direção da razão para qualquer um dos bens particulares que são objetivos possíveis da ação humana. No entanto, a capacidade humana de escolher o fim último concreto em vista do qual ele agirá não procede de nenhum absurdo da natureza humana e de sua condição. Esta capacidade tem seu fundamento imediato na multiplicidade de fins dentre várias sínteses entre as quais o homem pode escolher, e na capacidade que dá fundamento à capacidade de escolher. [...] Essa situação revela a pequenez e a grandeza da natureza humana. A pequenez aparece na própria debilidade do primeiro princípio da razão; este princípio por si só não é capaz de guiar a ação, e a instigação da inclinação natural e a inspiração da fé são necessárias para desenvolver uma lei adequada para a vida humana. A grandeza humana aparece na transcendência do mesmo princípio; ele evoca as possibilidades sem restringi-las, permitindo assim que o homem determine por sua própria escolha se viverá para o bem mesmo, ou para um bem em particular.

Ora, o agente público que assina um contrato administrativo ou publica um edital de licitação não age por reflexo ou de forma irracional. Age voluntariamente, de forma intencional e movido por um propósito, selecionando os meios para atingir um determinado fim. Cuida-se, nesse sentido, de uma ação estratégica, que pode ser avaliada em termos de eficácia; vale dizer, se teve sucesso ou se, ao contrário, falhou.

O aspecto estratégico não dá conta, no entanto, da integralidade do sentido da ação, que pode ser avaliada, ainda, em termos da sua racionalidade prática, vale dizer, da sua prudência e adequação aos valores coletivamente vinculados ao "bem viver", ou seja, àqueles valores escolhidos como os pilares de determinado modo de vida. 
Dessa maneira, ao assinar um contrato administrativo cujo edital sabidamente não foi antecedido pelo prazo mínimo de publicidade, o agente certamente descumpre as regras da Lei de Licitações e viola os princípios da legalidade e da competitividade das licitações. Contudo apenas se ele está - ou deveria estar - ciente de que isso poderia ser prejudicial à Administração Pública, ao reduzir a competitividade do certame, e se ele não tem outras razões de interesse público que justifiquem a ação é que o agente cruza o limite da ilicitude e ingressa no terreno da improbidade administrativa, pois é somente nessas circunstâncias que se pode afirmar que a conduta não era justificável, do ponto de vista dos princípios que regem a Administração Pública.

Isso se deve ao fato de que os atos de improbidade administrativa não são um tipo específico de atos, que são intrinsecamente reprováveis e sempre merecem punição, independentemente da finalidade que o agente tem em vista quando o pratica. Um ato de improbidade pode ser o ato de assinar um contrato, de publicar um edital ou de veicular uma propaganda institucional da prefeitura, desde que seja realizado por uma razão que se revela inadequada para justificá-lo. ${ }^{18}$ Apenas a avaliação do sentido que rege uma ação, portanto, é que permite classificar se o agente público praticou ou não um ato de improbidade administrativa.

Destaque-se que o sentido da ação ímproba é aquele orientado por finalidade ilegal, mas não necessariamente patrimonial. Assim, investigar o sentido da ação, avaliando as consequências ou finalidades buscadas pelo agente, não implica em demonstrar a ocorrência de dano ao erário ou de enriquecimento ilícito próprio ou de terceiro. De fato, desnecessário demonstrar que o ato alcançou determinada consequência ou finalidade ilícita do ponto de vista patrimonial, como aliás também caminham as decisões do STJ. ${ }^{19}$ Faz-se necessário, tão somente, avaliar se o ato se orienta no sentido de buscar vantagem indevida, seja ela relativa a poder, influência, aparência, ou qualquer outro objetivo que não poderia ser buscado pelo agente à frente do Poder Público.

\section{I. A importânCia do CONTEXTO}

A tese da voluntariedade (inicialmente defendida pelo Ministro Herman Benjamin, mas, depois, descartada pelo colegiado), assim como as versões conceituais de dolo genérico que o aproximam da responsabilidade objetiva, consideram dolo a intenção de praticar o ato, ainda que

18 A analogia aqui empregada é semelhante àquela realizada por Korsgaard (2008, p. 224) em relação ao homicídio, que, praticado em legítima defesa, em um contexto de guerra ou na execução de uma pena de morte, é valorativamente diferente do homicídio injustificado, que se converte em puro e simples assassinato.

19 "Esta Corte possui orientação consolidada [...] a qual o enriquecimento ilícito e o dano ao erário são desnecessários para a condenação com base no art. 11 da Lei n. 8.429/92” (STJ, AgInt nos EDcl no REsp n. 1745654/SP, Rel. Min. Regina Helena Costa, Primeira Turma, j. 05/02/2019). 
sem o propósito ou a consciência de que ele poderia alcançar resultados vedados pela norma jurídica. Dispensa-se, com isso, um exame mais pormenorizado do contexto para explicitar a vontade do agente em alcançar o resultado proibido da norma.

Todavia, se a ação humana é necessariamente ordenada segundo determinados fins, apenas compreendendo caso a caso a postura e situação de um dado agente público na qualidade de destinatário da norma jurídica é que se torna possível averiguar, ou não, a existência de dolo e de má-fé e, por consequência, de improbidade administrativa.

Um exemplo talvez possa tornar a questão mais clara. Suponha-se um caso de contratação de servidor sem concurso público. O art. 37, II, da Constituição prevê de forma inequívoca a necessidade da realização de certame para a investidura em cargo ou emprego público. Assim, nos termos da tese da voluntariedade, o dolo estaria configurado se manifesta a vontade de realizar a contratação ilegal, seria "dolo in re ipsa".

Imagine-se, no entanto, um cenário no qual um prefeito de uma cidade recebe recomendações do Tribunal de Contas para que exonere os ocupantes de cargos em comissão e realize os concursos públicos necessários para o provimento dos cargos municipais. Após promover a exoneração, o prefeito procede à recontratação temporária dos mesmos servidores, sem concurso público. Com base nessa descrição do cenário fático seria possível acusar o prefeito da prática de ato de improbidade administrativa nos termos do artigo 11 da Lei n. 8.429/1992, por violação dos deveres de honestidade e legalidade e ofensa aos princípios da moralidade e impessoalidade. Afinal, ao realizar a contratação, ele certamente tinha plena ciência de que ela deveria ser precedida por um concurso público.

É possível, no entanto, que essa recontratação tenha ocorrido em um contexto que a justifique. É o que se verificou em um caso, também apreciado pela Segunda Turma do STJ, que afastou a incidência da LIA por entender que, em um contexto de profunda reestruturação administrativa, a recontratação temporária de funcionários sem concurso público era justificável e atendia ao interesse público. Veja-se:

[...] Em primeiro lugar, não me parece razoável atribuir a nota de improbidade ao fato, isoladamente considerado, de o Prefeito Municipal ter contratado servidores temporários para atuarem em diversas áreas, tendo em vista a exoneração em massa de centenas de comissionados, realizada em obediência à decisão do TCE. Isso porque, mesmo se considerarmos, por hipótese, suficiente o prazo de 180 (cento e oitenta) dias fixado peloTCE para o provimento de cargos mediante concurso público, pelo menos durante esse lapso de tempo alguma solução de ordem administrativa tinha mesmo de ser tomada para impedir uma paralisação abruta na prestação de serviços públicos. Olhando por esse ponto de vista, não me parece demonstrada nenhuma evidência de que o Prefeito assim agindo tenha atuado com recalcitrância, má-fé, ou de maneira desleal, elemento subjetivo que qualifica a ação/omissão com a nota de ímproba. [...] Compulsando os 
autos, observo que, em verdade, o Município de Caruaru deflagrou três concursos distintos para o preenchimento de mais de mil cargos [...]. Faço esse registro para explicitar a dimensão da reestruturação administrativa que estava sendo implementada no Município, tarefa cujas proporções demandam cautela e não se pode executar em curto espaço de tempo. [...] o Prefeito demandado empenhou-se na edição de lei para a criação de diversos cargos, após o que sobreveio a realização de concursos [...].

A preservação temporária daqueles que já integravam o quadro de pessoal do Município pode mesmo ter sido a solução administrativa que melhor atendeu ao interesse público”. ${ }^{20}$

Como se vê, o Tribunal entendeu que a dispensa de centenas de servidores de cargos comissionados poderia levar a uma paralisação abrupta dos serviços públicos que seria prejudicial ao interesse público, justificando-se, portanto, a preservação temporária de funcionários que já atuavam no Município até que os concursos públicos necessários fossem realizados.

O exemplo acima evidencia que não é possível deduzir a prática de ato de improbidade da conduta em abstrato, ela não é evidente por si só, mas depende essencialmente da análise do contexto. Isso porque, como explica Korsgaard (2008, p. 221), quando se indaga pelas razões de uma dada ação, na realidade se está em busca de uma explicação para aquela ação específica, de uma descrição completa que nos permita compreender por que o agente entendeu que aquela conduta, naquele momento e daquela forma, seria adequada e justificada. A razão para uma ação conhecida só pode ser compreendida a partir do seu propósito ou fim, que deve ser inteligível como algo que vale a pena fazer em determinadas condições. ${ }^{21}$

Ressalte-se que não se trata, aqui, de uma pretensão a compreender as razões psicológicas ou sociológicas para a ação de um determinado agente empiricamente, mas de compreender se uma conduta pode ser racionalmente justificada por se orientar a determinados bens que devem ser perseguidos. No caso do agente público, como se verá com maior detalhe adiante, é certo que deve se orientar pela busca do interesse público. E é por meio de um processo

20 STJ, REsp n. 1660398, Rel. Min. Herman Benjamin, Segunda Turma, j. 27/06/2017, DJe: 30/06/2017, grifo nosso.

21 Como coloca a autora, "nós geralmente já conhecemos a ação, então a sua descrição depende de compreender o seu propósito ou fim. Ir a Chicago para visitar a mãe é um fim inteligível como algo que vale a pena fazer, então se entendemos esse propósito, conseguimos entender o que Jack fez [...]. Quando nós perguntamos pela razão de uma ação, nós não estamos apenas perguntando se ela atingiu o seu propósito - nós estamos perguntando por um propósito que dê sentido a ação de forma integral. Para que uma ação seja justificável, ela deve ser realizada da forma correta e no momento adequado" (KORSGAARD, 2008, p. 221-222, tradução livre do original). 
racional de particularização (determinatio) ${ }^{22}$ que se torna possível realizar a derivação normativa que indica o que se deve fazer em uma situação concreta e particular. ${ }^{23}$

Nesse sentido, adentrar a consciência do agente não é apenas impossível, como também desnecessário para fins de avaliação da conduta humana em termos de expressão particularizada da racionalidade prática. Nesse sentido, afasta-se da preocupação de que a exigência desse tipo de avaliação possa inviabilizar, na prática, a prova do elemento subjetivo necessária para garantir a efetividade da LIA. Essa avaliação, no entanto, depende de uma descrição adequada do contexto, como, aliás, já vem destacando alguns autores:

Em face da impossibilidade de se penetrar na consciência e no psiquismo do agente, o seu elemento subjetivo há de ser individualizado de acordo com as circunstâncias periféricas ao caso concreto, como o conhecimento dos fatos e das consequências, o grau de discernimento exigido para a função exercida e a presença de possíveis escusas, como a longa repetitio e a existência de pareceres embasados na técnica e na razão. (GARCIA e ALVES, 2014, p. 437)

Desse modo, é impossível a avaliação sobre o elemento subjetivo em um caso de improbidade administrativa sem a adequada instrução probatória e sem que os juízes elaborem seus votos a partir de um relatório completo e pormenorizado dos fatos. Caso contrário, estar-se-ia presumindo os fatos e, com isso, ocultando os reais motivos da tomada de decisão.

A este respeito, interessante notar que a jurisprudência do STJ vem defendendo que "o dolo exigido para configuração de ato de improbidade administrativa não se presume", ${ }^{\mathbf{2 4}}$ dado o caráter punitivo da lei e a gravidade das sanções nela previstas. A bem da verdade, no entanto,

22 A este respeito, Finnis (2005, p. 111) esclarece, com base em São Tomás de Aquino, que o direito positivo pode ser compreendido como derivado dos princípios da razão prática por meio de um processo, ainda que não dedutivo, ainda assim racional de especificação, a determinatio.

23 A possibilidade de derivar um dever a partir de um fato é bem explicada por Searle (1964), ao traçar a distinção entre os fatos brutos (encontrados na natureza independentemente de regras anteriores, como comer), e os fatos institucionais (que dependem de regras que os criem e definam novas formas de comportamento, como jogar xadrez). Segundo o autor, "é geralmente uma questão de fato que alguém tenha certas obrigações, compromissos, direitos e responsabilidades, mas é uma questão de fato institucional, e não bruto” (p. 56, tradução livre do original). Assim, a partir de um fato institucionalizado, como a promessa, é possível derivar o dever ser do ser, pois a regra constitutiva das promessas estabelece que prometer é assumir uma obrigação.

24 Nesse sentido, por exemplo, os seguintes julgados: STJ, AgRg no AREsp n. 184.923/SP, Rel. Min. Napoleão Nunes Maia Filho, Primeira Turma, j. 02/05/2013; STJ, REsp n. 1.365.529/PR, Rel. Min. Arnaldo Esteves Lima, Primeira Turma, j. 05/03/2013; STJ, REsp n. 939.118/SP, Rel. Min. Luiz Fux, Primeira Turma, j. 15/02/2011. 
tal afirmação não é precisa. Por sua própria natureza, o dolo e a má-fé não podem ser objeto de prova direta. A menos que haja uma confissão por parte do réu, o dolo e a má-fé só poderão ser determinados por uma operação racional, legitimamente realizada pelo julgador, a partir de fatos conhecidos e suficientemente provados. É apenas a partir do momento em que são inseridos em um discurso racional que os fatos provados podem conduzir à conclusão de que, em determinado contexto, a ação é justificável (ou não) em face dos princípios que regem a Administração Pública.

No caso em análise, o REsp n. 765.212/AC, os elementos fáticos à disposição da corte não eram exatamente pormenorizados, o que pode ter dificultado a tomada de decisão pelos ministros. O relatório, de uma página, traz apenas (i) o fundamento constitucional do REsp manejado; (ii) a transcrição da ementa do acórdão recorrido; (iii) o elenco das alegações de violação da legislação federal arguidas pelo recorrente, no caso o Ministério Público do Estado do Acre; e (iv) o dado sobre as páginas em que estão encartadas as contrarrazões dos agentes públicos e o parecer do Ministério Público Federal, que, na condição de custus legis, opinava pelo provimento do recurso.

Alguns outros dados sobre o caso podem ser extraídos dos votos dos ministros, mas as informações disponíveis são somente aquelas já veiculadas previamente: a ação de improbidade administrativa foi ajuizada pelo Ministério Público do Estado do Acre contra um ex-prefeito e uma ex-secretária municipal de uma cidade do interior do Estado, acusados de utilizar propaganda institucional para promoção pessoal. Isso porque as suas imagens foram veiculadas no meio de um comercial da prefeitura, com duração de 45 segundos, intitulado "Senador Guiomard - A Cidade do Novo Milênio", a qual custou aos cofres públicos R \$ 2.950,00 (dois mil, novecentos e cinquenta reais). O Tribunal de Justiça do Acre os absolveu por entender não estar configurado dolo.

Outras informações, no entanto, talvez pudessem ser úteis para a compreensão integral do problema. Não há informações, por exemplo, sobre como foi produzido o comercial, como se desenrolou o processo administrativo que lhe deu origem, se houve parecer de órgãos técnicos e jurídicos a embasar a decisão dos gestores, se a propaganda foi veiculada em ano eleitoral, ou que tipo de imagens dos agentes políticos foram veiculadas na propaganda e se traduziam uma mensagem meramente elogiosa e por quê.

A situação é agravada pelo fato de que o STJ é uma corte recursal que avalia apenas e tão somente teses jurídicas, cabendo ao Tribunal de origem avaliar o conjunto fático-probatório, descrevê-lo e, com base nele, julgar o caso. Nesse sentido, o próprio Ministro Mauro Campbell Marques em seu voto ressaltou que

o Superior Tribunal de Justiça, como instância uniformizadora da interpretação e da aplicação da legislação federal que é, não pode dizer que tais fatos não ocorreram, mas pode perquirir se eles ensejam ou não a configuração do dolo. [...] Esse comentário, conquanto simplório, e relevantíssimo, porque nas ações de proteção à moralidade 
administrativa é muito importante que as instâncias ordinárias façam análise criteriosa das provas produzidas no processo e pormenorizem as condutas judicialmente combatidas, para que não só seja garantida a qualidade de seus provimentos jurisdicionais, como também se possibilite a abertura ao Supremo Tribunal Federal e ao Superior Tribunal de Justiça. (p. 35)

Resta claro, assim, que a confecção de relatórios processuais detalhados é medida simples, porém absolutamente essencial para que se possa proceder, adequadamente, à imputação subjetiva nos casos de improbidade administrativa.

\subsection{OS PARÂMETROS DE AVALIAÇÃO: RACIOCÍNIO JURÍDICO E ADMINISTRAÇ̃̃O PÚBLICA}

Sustentou-se, até aqui, que indagar sobre o elemento subjetivo do ato de improbidade administrativa significa indagar o seu porquê, vale dizer, buscar as razões que orientam, justificam e tornam inteligível uma dada ação. A compreensão dessas razões passa necessariamente, como se disse, pelo contexto no qual a ação se desenrolou, de modo que, sem a identificação do momento e da forma pela qual determinado ato foi praticado, não é possível aferir sua adequação aos fins.

Para além da prova dos fatos circunstanciais perante os quais a ação do agente público se desenrolou, a avaliação das suas ações passa, ainda (e principalmente), pela compreensão dos bens que se almeja atingir por meio delas. É necessário compreender, a partir de uma postura de abstração empática, o ponto de vista do agente, pois a sua racionalidade é a condição de inteligibilidade das suas ações.

Ao tentar compreender os motivos da ação de um determinado agente, cabe ao julgador imaginar qual seria o pior motivo que aquela pessoa poderia ter para fazer o que fez, bem como qual seria o melhor motivo para explicar que ela tenha feito o que fez. Essas narrativas, geralmente, podem ser extraídas das peças de acusação e de defesa e deveriam, ambas, constar do relatório da decisão. Dessa forma, seria possível compreender as duas versões dos fatos e qual delas convenceu a corte, a quem caberá dizer, afinal de contas, qual das duas narrativas é mais condizente com a realidade e coerente com os fatos e provas apresentados pelas partes.

É importante considerar, ademais, que o ponto de vista do agente público, especialmente o do agente político, é o de cumprir um projeto de governo eleito, mobilizando os recursos públicos disponíveis para alcançar metas politicamente selecionadas por uma dada comunidade em um dado momento histórico. Cuida-se de um ponto de vista interno ao ordenamento jurídico que difere, substancialmente, do ponto de vista do juiz ou do promotor público, aos quais incumbe avaliar o cumprimento uma regra, a partir das categorias do proibido, do permitido e do obrigatório.

Se, para o juiz ou para o promotor de justiça, as leis servem como critério de julgamento da ação, para o agente público elas funcionam como orientações. Ocorre que, ao tomar 
decisões, o agente público não está inserido em uma lógica orientada exclusivamente para o cumprimento da lei ou de evitar a improbidade administrativa, mas o de governar ou administrar - ainda que, para tanto, deva evidentemente obedecer às leis, aos decretos e a uma série de outras normas jurídicas vigentes. ${ }^{25}$ Como esclarece Lopes (2004, p. 144):

Regras podem voltar-se para o passado ou para o futuro. Pode-se olhar para o passado e neste caso "julgá-lo", e pode-se olhar para o futuro e neste caso pensar sobre os "resultados da ação". As normas ou regras servem para estas duas tarefas. Quanto ao passado as normas podem "qualificar" o fato, [...] permitem "avaliar" ou "julgar" o que foi feito, saber se foi bom, se foi justo, se foi eficiente. Quanto ao futuro, as regras permitem-me fazer planos e imaginar resultados, que vão desde o resultado técnico (a construção de uma ponte) como resultados mais genéricos (a finalidade da minha vida, a sociedade justa). Nestes termos, as regras (técnicas, morais ou jurídicas) "orientam”, "norteiam”, ou “conduzem” à ação [...] É isto justamente o que diz Tomás de Aquino ao dizer que a lei está de duas formas na ação: uma como orientação, outra como critério de julgamento. (LOPES, 2004, p. 144)

Ao comparar o direito e a administração pública, fica claro que os respectivos raciocínios diferem porque as decisões serão avaliadas (criticadas) diferentemente. O sentido que se pode dar como resposta é diferente em cada um dos campos. No campo do direito, a crítica dá-se pela legalidade. No campo da administração pública, a crítica e a avaliação podem ser feitas em termos da persecução do interesse público, traduzido em uma série de princípios que orientam e pautam a Administração - e que incluem não só a legalidade, mas também a eficiência, a impessoalidade, moralidade e a publicidade.

Como se viu nos exemplos anteriormente analisados, em alguns casos, condutas que violam determinadas regras jurídicas podem se justificar diante de outros deveres, também assumidos pelo agente público - e que correspondem a interesses também juridicamente protegidos - como a proteção da estabilidade, da segurança jurídica e da continuidade dos serviços públicos. Em outros casos, condutas que parecem, a princípio, autorizadas pelas normas vigentes podem estar orientadas a objetivos ilegítimos, de promoção de interesses privados às custas de recursos públicos. Essa distinção, contudo, só é possível a partir da compressão do ponto de vista do agente e da sua racionalidade.

25 A racionalidade do agente público pode ser comparada, para fins de clareza do argumento, à racionalidade do motorista, que busca chegar a algum lugar e deve, ao mesmo tempo, não desobedecer às regras de trânsito. Ora, é certo que as regras de trânsito limitam e organizam a sua ação, mas um motorista que, de madrugada, em uma região perigosa, deixa de parar diante de um semáforo fechado pode ser isentado da punição por parte do agente de trânsito, por se entender que a sua conduta se justifica. 
Como bem aponta Winch (1956, p. 32), para entender o que está acontecendo em uma sociedade, é necessário entender as regras segundo as quais aquelas atividades estão sendo desempenhadas. A partir do momento que se conhece a regra que um indivíduo está seguindo, é possível compreender e, em muitos casos, antecipar a sua conduta. Em alguns casos, no entanto, mesmo conhecendo a regra que uma pessoa está seguindo não é possível prever com certeza a sua conduta diante de uma determinada situação, pois se está diante de circunstâncias marcadamente diferentes daquelas em que a regra havia sido aplicada anteriormente. Nesses casos, o indivíduo deve interpretar a regra e tomar uma decisão, que pode ser avaliada como mais ou menos certa, em função da sua consistência com as regras invocadas para justificá-la (WINCH, 1956, p. 22-23).

Assim, sem compreender como se dá a gestão pública, não é possível avaliar a racionalidade de alguém que age na qualidade de gestor público, com vistas à realização de determinados projetos, à manutenção e melhoria dos serviços públicos e da estrutura administrativa. Apenas compreendendo o que faz o gestor público é possível traçar parâmetros de avaliação que sejam compatíveis com a racionalidade efetivamente empregada no seu agir.

Evidentemente, o agente público deve pautar sua conduta pelos princípios da legalidade, moralidade, impessoalidade, lealdade às instituições. Isso, no entanto, não isenta os tribunais e doutrinadores de fazer uma discussão mais aprofundada sobre o que esses princípios representam na prática e qual é o parâmetro de ação esperado de um agente público. Afinal, ao se avaliarem práticas sociais específicas e orientadas segundo uma razão institucional, ${ }^{26}$ é preciso ter clareza da ação ideal que se espera do agente público.

Não é possível dizer se o resultado do REsp n. 765.212/AC, ora analisado, teria sido diferente caso fossem adotados os critérios de julgamento até aqui defendidos. É possível que o STJ tivesse chegado, da mesma forma, à conclusão de que os agentes políticos atuaram de maneira dolosa no sentido de violar o princípio da impessoalidade e que, portanto, deveriam ser condenados às sanções previstas na LIA. É certo, todavia, que a elaboração de um relatório mais pormenorizado, trazendo a explicação das partes sobre a motivação do ato e uma análise mais detalhada de contexto, bem como a avaliação, nos votos, do sentido da ação dos agentes implicados, certamente faria com que a justificação da decisão tivesse mais consistência, força e, por consequência, legitimidade.

26 Adota-se, aqui, o termo "razão institucional" no sentido sugerido por Searle (1964), para se referir às razões de agir que orientam o agente diante de determinadas regras constitutivas de uma determinada prática social. Como esclarece o autor, “[...] um homem tem 5 dólares, em razão da instituição 'dinheiro'. Tire a instituição e tudo o que ele tem é um pedaço de papel retangular pintado de verde” (SEARLE, 1964, p. 54). Instituições como o dinheiro, o casamento e as promessas são sistemas constituídos por regras e convenções das quais decorrem direitos, deveres e padrões adequados de comportamento. Isso também se pode dizer das instituições que constituem e organizam o Estado e a Administração Pública. 
Esse resgate da noção de razão prática poderia, inclusive, contribuir para a discussão sobre a complexa dosimetria das sanções concretamente aplicadas a casos de improbidade administrativa. De fato, a LIA determina que as sanções aos atos de improbidade administrativa serão aplicadas isolada ou cumulativamente, a depender da gravidade dos fatos e levando em conta a extensão do dano e o proveito patrimonial obtido pelo agente. Evidentemente, na falta de dano ao erário e de proveito patrimonial, a sanção deve ser minorada, mas a gravidade da conduta do réu poderia ser melhor compreendida a partir da noção de razão prática como critério interpretativo - ainda que não se trate, evidentemente, da panaceia de todas as dificuldades dogmáticas impostas pela LIA. ${ }^{27}$

\section{CONCLUSÃo}

Na aplicação da LIA, a jurisprudência do STJ vem debatendo a necessidade de demonstração de dolo ou culpa para que se proceda à responsabilização do agente público que viola os deveres de honestidade, imparcialidade, legalidade e lealdade às instituições e, assim, atenta contra os princípios da Administração Pública. Mais recentemente, o tribunal firmou entendimento de que é necessária a demonstração de que o agente atuou com dolo, não se punindo como ímprobas as condutas culposas. Isso significa que havendo negligência, imprudência ou imperícia, haverá irregularidade administrativa a ser sancionada em outras esferas de controle, mas não pela Lei n. 8.429/1992.

Nesse sentido, como coloca o Ministro Mauro Campbell em seu voto no REsp n. 765.212/ AC, "seria acaso imaginável que alguém pudesse ser desleal ou desonesto sem querer? É possível ser ímprobo a título de culpa? A resposta só pode ser negativa, pois os conceitos de probidade e improbidade exigem necessariamente o querer, o agir com vontade" (p. 32). A improbidade, assim, só se configura nos casos em que a ilegalidade cometida é qualificada pela intencionalidade contrária ao sentido da norma, pela má-fé.

O dolo que se exige, nos termos das decisões recentes do STJ, ${ }^{28}$ no entanto, é o dolo genérico ou lato sensu, que vem sendo conceituado como a vontade de realizar fato descrito na norma incriminadora, bastando a comprovação da vontade consciente de aderir à conduta,

27 A falta de critérios mais objetivos para a dosimetria das sanções talvez só possa ser sanada, efetivamente, pela via da alteração legislativa. A este respeito, ressalte-se que tramitam, na Câmara dos Deputados, diversos projetos de lei com vistas à alteração do regime de processamento das Ações de Improbidade Administrativa, como o PL 233/2015 e o PL 10.887/2018.

28 "É pacífica a jurisprudência desta Corte de que o ato de improbidade administrativa previsto no art. 11 da Lei n. 8.429/1992 exige a demonstração de dolo, o qual, contudo, não necessita ser específico, sendo suficiente o dolo genérico" (AgInt no REsp n. 876.248/ MA, Rel. Min. Herman Benjamin, Segunda Turma, DJe: 29/09/2016, grifo nosso). 
produzindo os resultados vedados pela norma jurídica ou, ainda, a simples anuência aos resultados contrários ao Direito quando o agente público ou privado deveria saber que a conduta praticada a eles levaria. ${ }^{29}$

O presente artigo procurou evidenciar, no entanto, que a busca do Tribunal pelo elemento subjetivo doloso para a configuração do ato de improbidade administrativa que viola os princípios da Administração Pública (art. 11, Lei n. 8.429/1992) padece de considerável falta de clareza, uma vez que não se baseia em uma teoria mais sólida acerca da ação humana.

O Tribunal descartou, acertadamente, a tese da voluntariedade, concluindo pela necessidade de se perquirir acerca da finalidade da ação praticada. De fato, toda ação humana é necessariamente orientada a determinados fins. Ao excluir a análise da finalidade da ação, a tese da voluntariedade terminava por admitir a responsabilização objetiva do agente público.

Cuida-se, sem dúvida, de um avanço, mas talvez não seja suficiente para responder à pergunta que se coloca: "por quê?”. Ora, indagar sobre o elemento subjetivo da ação, que abrange o dolo e a má-fé do agente público, para fins de aplicação da LIA, é indagar sobre as razões que expliquem e, eventualmente, justifiquem uma determinada conduta.

Assim, a partir de um resgate da noção clássica de razão prática, sugeriu-se uma distinção entre o comportamento irracional de um lado, o ato voluntário orientado a determinados fins de outro, e, ainda, a ação racional dotada de sentido. A distinção, acredita-se, permite ter clareza de que nem toda conduta ilegal, ainda que intencional e voluntária, é injustificável do ponto de vista dos princípios que regem a Administração Pública. Da mesma forma, nem toda conduta formalmente legal deixa de ser ímproba, pois pode estar orientada a objetivos ilegítimos, de promoção de interesses privados às custas de recursos públicos.

De fato, diferentemente dos ilícitos penais, como matar alguém, os atos de improbidade administrativa não são um tipo específico de ato intrinsecamente reprovável. Via de regra, cuida-se de atos administrativos aparentemente regulares - os atos de assinar um contrato, de publicar um edital ou de veicular uma propaganda institucional convertem-se em ímprobos, a depender da finalidade que o agente tem em vista quando o pratica e se as razões que ele fornece para praticá-lo se revelam adequadas aos princípios que regem a Administração Pública.

Do ponto de vista dos tribunais, perquirir sobre a existência de um ato de improbidade depende de investigar o sentido da ação, o que depende, largamente, do contexto. O sentido de uma ação específica só pode ser compreendido circunstancialmente, se inserido no tempo e no espaço. Por esse motivo, é absolutamente imprescindível que o processo judicial se preste a provar adequadamente os fatos que circundam uma conduta supostamente ímproba. É

29 STJ, REsp n. 765.212/AC, Rel. Min. Herman Benjamin, Segunda Turma, j. 02/03/2010, DJe: 23 jun. 2010, p. 34. No mesmo sentido, ver STJ, AgRg no REsp n.1.539.929/MG, Rel. Min. Mauro Campbell Marques, Segunda Turma, DJe: 02/08/2016. 
essencial, ainda, que a motivação da decisão judicial nas ações de improbidade se dedique a revelar inteligibilidade da ação do agente público, levando em conta que o administrador público age no sentido de realizar projetos públicos e não apenas com vistas a evitar a ilegalidade.

Deixar de explicitar o contexto ou os princípios que estão em jogo em uma decisão tomada por um agente público equipara-se a presumir o seu dolo no caso concreto, ocultando vícios na motivação de sentenças e acórdãos, na medida em que não ficam claros ou explicitados os reais motivos de decidir. Certamente, a decisão judicial não é um ato de subsunção lógica, mas uma prática interpretativa que deve estar submetida à adequada justificação, sob pena de esconder, sob um verniz de legitimidade, ares de arbitrariedade judicial.

\section{REFERÊNCIAS}

BRASIL. Lei n. 8.429, de 2 de junho de 1992. Disponível em: http:/ / www.planalto.gov.br/ccivil_03/ LEIS/L8429.htm. Acesso em: 19 set. 2019.

CARVALHO FILHO, José dos Santos. Manual de Direito Administrativo. 32. ed. São Paulo: Atlas, 2018.

DI PIETRO, Maria Sylvia Zanella. Direito Administrativo. 30. ed. Rio de Janeiro: Forense, 2017.

FACCHINI, Maria Iraneide Olinda Santoro. Improbidade e dolo na jurisprudência do Superior Tribunal de Justiça. Boletim Científico MPU, a. 10, n. 36, Brasília, 2011. p. 53-65.

FINNIS, John. Foundations of Practical Reason Revisited. Journal Articles. Notre Dame Law School, v. 50, Paper 868, 2005. Disponível em: http://scholarship.law.nd.edu/law_faculty_scholarship/868. Acesso em: 17 set. 2019.

GARCIA, Emerson; ALVES, Rogério Pacheco. Improbidade administrativa. 8. ed. São Paulo: Saraiva, 2014.

GIACOMUZZI, José Guilherme. A moralidade administrativa: história de um conceito. Conferência proferida pelo autor na aula final de formatura dos alunos da Escola Superior do Ministério Público do Rio Grande do Sul. Porto Alegre, 2002.

GIACOMUZZI, José Guilherme. A moralidade administrativa e a boa-fé da Administração Pública - O conteúdo dogmático da Moralidade Administrativa. 2. ed. São Paulo: Malheiros, 2013. 
GRISEZ, Germain. O primeiro princípio da razão prática. Tradução de José Reinaldo Lima Lopes. São Paulo, Revista Direito GV, v. 3, n. 1, p. 51-89, 2007.

JURUENA, Cynthia Gruendling; LEAL, Rogério Gesta. Interlocuções necessárias entre moralidade administrativa e probidade administrativa. Barbarói, Edição Especial, n. 42, p. 268-287, 2014.

JUSTEN FILHO, Marçal. Curso de Direito Administrativo. 12. ed. São Paulo: Revista dos Tribunais, 2016.

KORSGAARD, Christine M. The constitution of agency: essays on practical reason and moral psychology. New York: Oxford University Press, 2008.

LOBO DA COSTA, Regina Helena. Direito Administrativo Sancionador e Direito Penal: a necessidade de desenvolvimento de uma política sancionadora integrada. In: BLAZECK, Luiz Maurício Souza; MARZAGÃO JÚNIOR, Laerte I. (coords.). Direito Administrativo Sancionador. São Paulo: Quartier Latin, 2014.

LOPES, José Reinaldo Lima. Raciocínio jurídico e economia. Revista de Direito Público da Economia, ano 2, n. 8, p. 137-170, 2004.

MICHELON, Claudio. Practical wisdom in legal decision-making. Working Paper Series, n. 13, 2010, University of Edinburgh, School of Law. Disponível em: http: / / ssrn.com/abstract=1585929. Acesso em: 17 set. 2019.

NEISSER, Fernando Gaspar. A responsabilidade subjetiva na improbidade administrativa: um debate pela perspectiva penal. Tese (Doutorado em Direito), 2018. São Paulo: Faculdade de Direito da Universidade de São Paulo, 2018.

NUCCI, Guilherme de Souza. Manual de Direito Penal. 14. ed. Rio de Janeiro: Forense, 2018.

OSÓRIO, Fábio Medina. Teoria da improbidade administrativa: má gestão pública, corrupção, ineficiência. 4. ed. São Paulo: Thomson Reuters Brasil, 2018.

PRADO, Luiz Regis. Curso de Direito Penal Brasileiro. 13. ed. São Paulo: Revista dos Tribunais, 2014.

SANTOS, Lyts de Jesus. Há improbidade por violação a princípios sem dano ao patrimônio público? Revista da $A G U$, ano 10, n. 30, Brasília, dez. 2011. Disponível em: https://www.agu.gov.br/page/download/ index/id/7983748. Acesso em: 17 set. 2019.

SEARLE, John R. How to derive 'ought' from 'is'. The Philosophical Review, v. 73, n. 1, p. 43-58, 1964. Disponível em: http://www.jstor.org/stable/2183201. Acesso em: 17 set. 2019. 
SIMÃO, Calil. Improbidade administrativa: teoria e prática. Leme: J. H. Mizuno, 2011.

WINCH, Peter. Social Science. The British Journal of Sociology, v. 7, n. 1, p. 18-33, 1956. Disponível em: http://www.jstor.org/stable/588128. Acesso em: 17 set. 2019.

YIN, Robert T. Estudo de caso: planejamento e métodos. 4. ed. Porto Alegre: Bookman, 2010.

\section{COMO CITAR ESTE ARTIGO:}

FERREIRA, Vivian Maria Pereira. 0 dolo da improbidade administrativa: uma busca racional pelo elemento subjetivo na violação aos princípios da Administração Pública. Revista Direito GV. v. 15, n. 3, set./dez. 2019, e1937. doi: http://dx.doi.org/10.1590/23176172201937.

\section{Vivian Maria Pereira Ferreira}

Mestre em Direito e Desenvolvimento pela Escola de Direito de São Paulo da Fundaç̃o Getulio Vargas (FGV DIREITO SPI. DOUTORANDA EM FILOSOFIA DO DIREITO NA Universidade de SÃo PaUlo (USP). vivianmpferreira@gmail.com 